\title{
ADDITION OF VITERNA WITH DIFFERENT DOSAGE ON PELLET FEED ON GROWTH OF GROUPER FISH SEED (Cromileptis altivelis)
}

\author{
Muhammad Irfan $^{* 1}$, Syafruddin Nasution ${ }^{2}$, Irvina Nurrachmi ${ }^{2}$ \\ ${ }^{1}$ Student of The Faculty of Fisheries and Marine Universitas Riau, Pekanbaru \\ ${ }^{2}$ Lecturer at The Faculty of Fisheries and Marine Universitas Riau, Pekanbaru \\ *moirfan8228@gmail.com
}

\begin{abstract}
This research was conducted from 15 June - 27 July 2019 in the Regional Technical Implementation Unit of The Seawater and Brackish Aquaculture. (UPTD BPBALP Teluk Buo), West Sumatra. This study aim to determine the best of viterna multivitamin right on the growth and the survival of grouper fish (Cromileptis altivelis) seed. The method used in this study was an experimental method using a complete randomized design (RAL) with 4 treatments (A: $0 \mathrm{ml} / \mathrm{kg}$ of feed, B: $10 \mathrm{ml} / \mathrm{kg}$ of feed, C: $15 \mathrm{ml} / \mathrm{kg}$ of feed and D: $20 \mathrm{ml} / \mathrm{kg}$ of feed). Parameters in this research are absolute weight growth, absolute length growth, specific growth rate and survival rate. The results of this research are to find out the best viterna multivitamin dose for absolute weight growth was $10 \mathrm{ml} / \mathrm{kg}$ of feed, absolute length growth was $10 \mathrm{ml} / \mathrm{kg}$ of feed, the specific growth rate was $10 \mathrm{ml} / \mathrm{kg}$ of feed and survival rate was $100 \%$ of all treatments.
\end{abstract}

Keywords: Viterna dose, growth, survival rate, Cromileptis altivelis

\section{PENDAHULUAN}

Ikan kerapu bebek (Cromileptis altivelis), merupakan jenis ikan air laut yang memiliki prospek menjanjikan dan mulai merebut perhatian pelaku usaha budidaya.Permintaan ikan kerapu terus meningkat setiap tahunnya. Ikan kerapu banyak disukai masyarakat karena rasa dagingnya yang khas. Dalam usaha budidaya sektor perikanan, pakan merupakan faktor penting terhadap keberhasilan budidaya ikan. Kualitas pakan dapat mempengaruhi pertumbuhan ikan, jika kualitasnya baik maka nutrisi untuk pertumbuhan pun akan terpenuhi secara maksimal.

Kebutuhan pakan selama budidaya dapat mencapai sekitar $60-70 \%$, dari biaya operasional budidaya (Hadadi et al., 2009). Pakan yang diberikan pada ikan dinilai baik tidak hanya dari komponen penyusun pakan tersebut melainkan juga dari seberapa besar komponen yang terkandung dalam pakan mampu diserap dan dimanfaatkan oleh ikan dalam kehidupannya.

Pakan yang diproduksi dengan harga mahal pun belum tentu memiliki kualitas yang baik oleh karena itu, perlu dicari alternatif bahan pakan yang dapat membantu dalam proses pencernaan pakan. Salah satu alternatif yang dikembangkan untuk mempercepat pertumbuhan adalah viterna. Viterna merupakan multivitamin pakan dari PT. Natural Nusantara yang diolah dari berbagai macam bahan (hewan dan tumbuhan), manfaat yang terdapat yaitu dapat meningkatkan nafsu makan hewan, meningkatkan daya tahan tubuh, memacu enzim-enzim pencernaan serta mempercepat pertumbuhan. Viterna plus diformulasikan dengan basis teknologi 
asam amino yang berfungsi menambah dan melengkapi nutrisi ternak karena viterna merupakan multivitamin atau penambah nutrisi murni yang siap dicerna serta mampu meningkatkan efektifitas dan efisiensi pencernaan ternak.

Balai Perikanan Budidaya Air Laut dan Payau (BPBALP) Teluk Buo, telah mengembangkan usaha budidaya ikan kerapu bebek dengan penerapan teknologi pendederan sehingga menghasilkan benih ikan kerapu yang memiliki kualitas baik dan jumlah yang tersedia secara kontinyu. Masalah dalam penelitian ini adalah bagaimana pengaruh pemberian vitamin viterna dengan dosis berbeda terhadap pertumbuhan benih ikan kerapu bebek (C.altivelis).

Penelitian mengenai penambahan viterna dengan dosis yang bereda ada pakan telah diakukan sebelumnya oleh Hendrasaputro (2015), penelitian ini menggunakan ikan Lele Sangkuriang (Clarias gariepinus) di Balai Benih kota Gorontalo. Hasil penelitian tersebut didapatkan bahwa pemberian viterna dengan dosis $15 \mathrm{ml} / \mathrm{kg}$ pakan memberikan pertumbuhan berat mutlak dan harian tertinggi.

\section{METODE PENELITIAN}

Penelitian ini telah dilaksanakan selama 40 hari pada tanggal 15 Juni - 27 Juli 2019, di UPTD BPBALP (Unit Pelaksana Teknis Daerah Balai Perikanan Budidaya Air Laut dan Payau) Teluk Buo, Kota Padang, Provinsi Sumatera Barat

Alat yang digunakan dalam penelitian ini adalah bak beton sebagai wadah

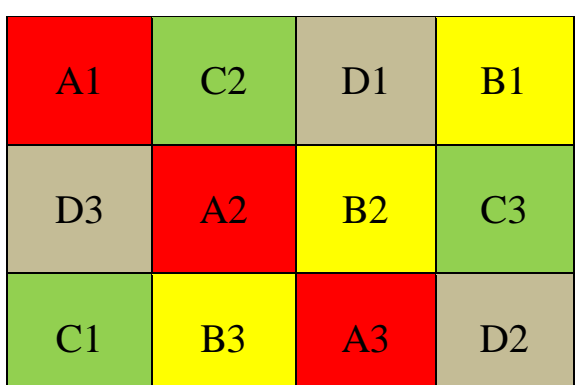

Gambar 1. Desain Penelitian pemeliharaan benih ikan, pemberat, timbangan digital dan penggaris untuk mengukur panjang benih, refraktometer, DO meter, dan $\mathrm{pH}$ meter untuk mengukur kualitas media uji, alat tulis dan kamera sebagai alat dokumentasi. Bahan yang digunakan adalah benih ikan kerapu bebek, pakan Megami, dan air laut.

Penelitian ini menggunakan metode eksperimen dengan 4 perlakuan (A: $0 \mathrm{ml} / \mathrm{kg}$ pakan, B: $10 \mathrm{ml} / \mathrm{kg}$ pakan, C: $15 \mathrm{ml} / \mathrm{kg}$ pakan dan D: $20 \mathrm{ml} / \mathrm{kg}$ pakan) dan 3 ulangan sehingga jumlah satuan percobaan adalah 12 unit. Penelitian ini dimulai dari mempersiapkan wadah berupa bak beton berukuran $500 \times 200 \times 100 \mathrm{~cm}^{3}$ yang dibersihkan dengan cara disikat dan dibilas air mengalir, kemudian dipasang waring berukuran 40x30x60 $\mathrm{cm}^{3}$. Mata waring yang digunakan berukuran $4 \mathrm{~mm}$ dan terbuat dari bahan polyethylene berwarna hitam. Kemudian mempersiapkan hewan uji dengan melakukan pemberokan dan aklimatisasi. Penyiponan dan penggantian air dilakukan 2 kali sehari pada pukul 07.00 WIB dan pukul 17.00 WIB. Air yang diganti sebanyak $30 \%$ dari jumlah air keseluruhan (Rayes et al., 2013).

Pengukuran parameter uji dilakukan pada hari ke-0, hari ke-10, hari ke-20, hari ke-30 dan hari ke-40. Pemberian pakan terhadap benih sebanyak 5\% dari bobot tubuh benih dengan frekuensi pemberian pakan sebanyak 3 kali sehari pada pukul 08.00, 13.00 dan pukul 16.00 WIB (Rayes et al., 2013). Desain eksperimen disajikan pada Gambar 1.

Keterangan:
a) Perlakuan A: $0 \mathrm{ml} / \mathrm{kg}$
b) Perlakuan B: $10 \mathrm{ml} / \mathrm{kg}$
c) Perlakuan C: $15 \mathrm{ml} / \mathrm{kg}$
d) Perlakuan D: $20 \mathrm{ml} / \mathrm{kg}$ 


\section{Pertumbuhan Bobot Mutlak}

Menurut Effendi (1979) Pertumbuhan berat mutlak dapat dihitung dengan rumus:

Keterangan:

$$
W=W t-W o
$$

$\mathrm{Wt}=$ Berat Akhir $(\mathrm{g})$

$\mathrm{W} 0=$ Berat Awal $(\mathrm{g})$

\section{Pertumbuhan Panjang Mutlak}

Pertumbuhan panjang ditetapkan bedasarkan pertambahan panjang ikan uji pada setiap uni percobaan, menurut Effendi (1997) pertumbuhan panjang mutlak dapat dihitung dengan rumus:

Keterangan:

$$
\Delta L=L t-L o
$$

$\mathrm{Lt}=$ Panjang Akhir $(\mathrm{cm})$

$\mathrm{L} 0=$ Panjang Awal $(\mathrm{cm})$

\section{Laju Pertumbuhan Harian}

Perhitungan pada parameter pertumbuhan berat harian rata-rata dengan menggunakan rumus menurut Muchlisin et al. (2016) adalah:

$$
S G R=\frac{W t-W o}{T}
$$

Keterangan:

$\mathrm{Wt}=$ Bobot ikan diakhir penelitian $(\mathrm{g})$

Wo $=$ Bobot ikan diawal penelitian $(\mathrm{g})$

$\mathrm{T}=$ Lama Pemeliharaan (hari)

\section{HASIL DAN PEMBAHASAN Pertumbuhan Berat Mutlak}

Nilai pertumbuhan rata-rata bobot ikan kerapu bebek tertinggi terdapat pada perlakuan B yaitu sebesar 5,07 $\mathrm{g}$ dan pertumbuhan yang terendah terdapat pada perlakuan A yaitu sebesar 3,91 g, disajikan pada Gambar 2.

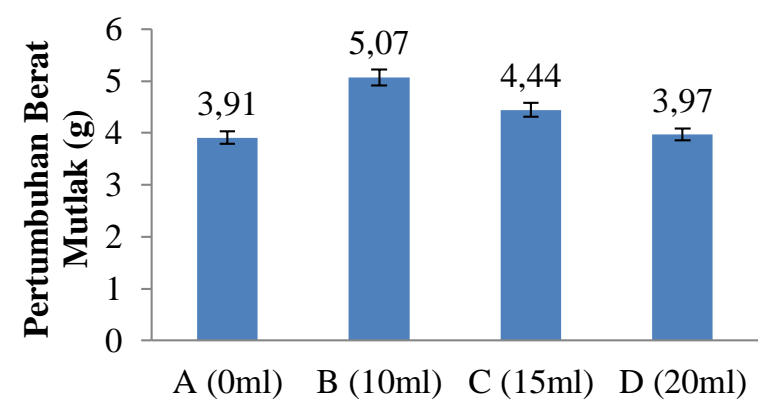

Gambar 2. Rata-rata pertumbuhan bobot mutlak benih ikan kerapu bebek

Berdasarkan hasil analisis variansi (ANOVA), perlakuan dengan dosis vitamin viterna yang berbeda berpengaruh nyata terhadap pertumbuhan bobot mutlak benih ikan kerapu bebek dengan nilai probabilitas $0,00<0,05$. Kemudian dilakukan uji lanjut Least Significant Difference. Hasilnya perlakuan A berbeda nyata dengan perlakuan $\mathrm{B}$ dan $\mathrm{C}$, namun tidak berbeda nyata dengan perlakuan $\mathrm{D}$.

Berdasarkan hasil penelitian ini, diperoleh dosis terbaik untuk seluruh parameter uji yaitu pada perlakuan $\mathrm{B}$, dan yang terendah pada perlakuan $\mathrm{A}$. Hal ini diduga perlakuan $\mathrm{B}$ yang memperoleh dosis viterna $10 \mathrm{ml} / \mathrm{kg}$ mampu memanfaatkan dosis multivitamin dan pakan yang secara rutin diberikan setiap harinya, sehingga dapat meningkatkan laju pertumbuhan ikan. Dibandingkan dengan kajian lainnya seperti kajian oleh Hendrosaputro et al. (2015), menunjukkan bahwa penambahan viterna pada pakan juga dapat mempengaruhi pertumbuhan pada ikan lele (Clarias sp.) dengan dosis terbaik diperoleh pada 15 $\mathrm{ml} / \mathrm{kg}$ pakan (15 ppt). Sedangkan Mufidah et al. (2009), penambahan multivitamin viterna pada pakan alami (Daphnia sp.) larva ikan lele dumbo diperoleh dosis terbaik pada $10 \mathrm{ml} / \mathrm{l}$ air (10 ppt). Nutrisi 
yang berlebihan pada pakan ikan dapat menghambat laju pertumbuhan ikan.

Viterna dengan dosis berbeda yang telah dicampurkan ke dalam pakan mempunyai kandungan seperti protein dan lemak yang akan dicerna oleh ikan untuk kebutuhan energi dan pertumbuhan. Berdasarkan hasil analisis variansi pertumbuhan berat mutlak ikan kerapu bebek menunjukkan $\mathrm{P}<0,05$ dengan taraf kepercayaan $95 \%$, yang berarti bahwa pemberian viterna dengan dosis berbeda pada pakan memberikan pengaruh nyata untuk pertumbuhan ikan kerapu bebek.

Hal ini disebabkan ikan kerapu bebek mempunyai sifat karnivora. Ikan karnivora mempunyai kemampuan memanfaatkan protein lebih baik dari pada lemak dan karbohidrat. Sehingga pada penelitian ini diduga ikan kerapu bebek memanfaatkan energi untuk pertumbuhan adalah dengan mencerna protein lebih banyak. Menurut Kordi (2009), kekurangan protein berpengaruh negatif terhadap konsumsi pakan, konsekuensinya terjadi penurunan pertumbuhan bobot. Kelebihan protein dan lemak dapat menimbulkan penimbunan lemak, nafsu makan ikan berkurang. Nilai nutrisi (gizi) pakan pada umumnya dilihat dari komposisi zat gizi dan berapa komponen nutrisi yang penting dan harus tersedia dalam pakan, antara lain protein, lemak, karbohidrat, dan vitamin.

Sedangkan perlakuan A tanpa pemberian multivitamin viterna pada pakan menunjukkan pertumbuhan panjang mutlak terendah dibandingkan perlakuan lainnya. Hal ini diduga dipengaruhi oleh aktivitas fisik ikan dan kebutuhan nutrisi ikan yang tidak terpenuhi secara optimal. Ikan kerapu bebek merupakan jenis ikan karnivora yang memakan ikan-ikan kecil dan krustacea. Sedangkan benih memangsa larva moluska, zooplanton, cephalopoda dan rotifer. Dimana ikan karnivora membutuhkan nutrisi lebih banyak dari jenis ikan herbivora, khususnya kandungan protein. Dimana faktor yang mempengaruhi pertumbuhan ikan adalah kandungan protein dalam pakan, sebab protein berfungsi membentuk jaringan baru untuk pertumbuhan dan menggantikan jaringan yang rusak.

\section{Pertumbuhan Panjang Mutlak}

Nilai pertumbuhan rata-rata panjang ikan kerapu bebek tertinggi selama masa pemeliharaan terdapat pada perlakuan B yaitu sebesar $2,69 \mathrm{~cm}$ dan pertumbuhan rata-rata panjang yang terendah terdapat pada perlakuan A yaitu sebesar $1,87 \mathrm{~cm}$, disajikan pada Gambar 3.

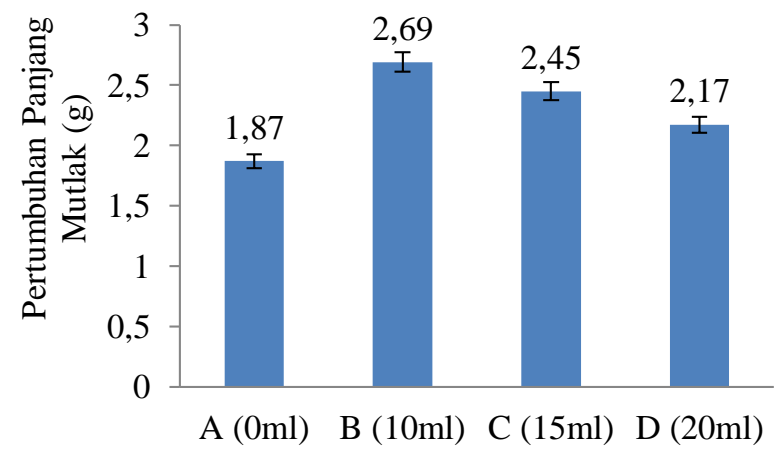

Gambar 3. Rata-rata pertumbuhan panjang mutlak benih ikan kerapu bebek

Berdasarkan hasil analisis variansi (ANOVA), perlakuan dengan dosis vitamin viterna yang berbeda berpengaruh nyata terhadap pertumbuhan bobot mutlak benih ikan kerapu bebek dengan nilai probabilitas $\quad 0,00<0,05$. Kemudian dilakukan uji lanjut Least Significant Difference. Hasilnya perlakuan A berbeda dengan perlakuan $\mathrm{B}, \mathrm{C}$, dan $\mathrm{D}$. Pertumbuhan panjang mutlak benih ikan 
kerapu bebek dengan pemberian dosis viterna $10 \mathrm{ml} / \mathrm{kg}$ diduga mencukupi kebutuhan nutrisi ikan khususnya protein, sehingga ikan dapat tumbuh dengan optimal. Sedangkan benih ikan kerapu bebek tanpa tambahan viterna pada pakan tidak dapat memenuhi kebutuhan untuk pertumbuhan ikan.

Berdasarkan pengamatan visual selama pemeliharaan, respon makan ikan dengan perlakuan pakan yang ditambah viterna mengalami peningkatan nafsu makan dibandingkan pakan kontrol. Hal ini diduga dipengaruhi oleh nilai nutrisi pakan, pada umumnya dari komposisi zat gizi dan komponen nutrisi yang penting dan harus tersedia dalam pakan, diantaranya protein, lemak, karbohidrat dan vitamin yang terpenuhi. Sehingga ikan yang ditambahkan multivitamin viterna pada pakan dapat memenuhi kebutuhan nutrisi. Kemudian energi yang dihasilkan dapat digunakan ikan untuk mencari makan dan aktifitas lainya. Sesuai dengan pernyataan Kurnia (2008) bahwa energi yang dihasilkan lemak digunakan untuk mencari makan, menghindari musuh dan pertumbuhan.

\section{Laju Pertumbuhan Spesifik (Specific Growth Rate)}

Nilai rata-rata laju pertumbuhan spesifik benih ikan kerapu bebek yang tertinggi selama masa pemeliharaan adalah perlakuan B yaitu sebesar 12,68\% dan laju pertumbuhan harian yang terendah terdapat pada perlakuan A yaitu sebesar 9,77\%, disajikan pada Gambar 4.

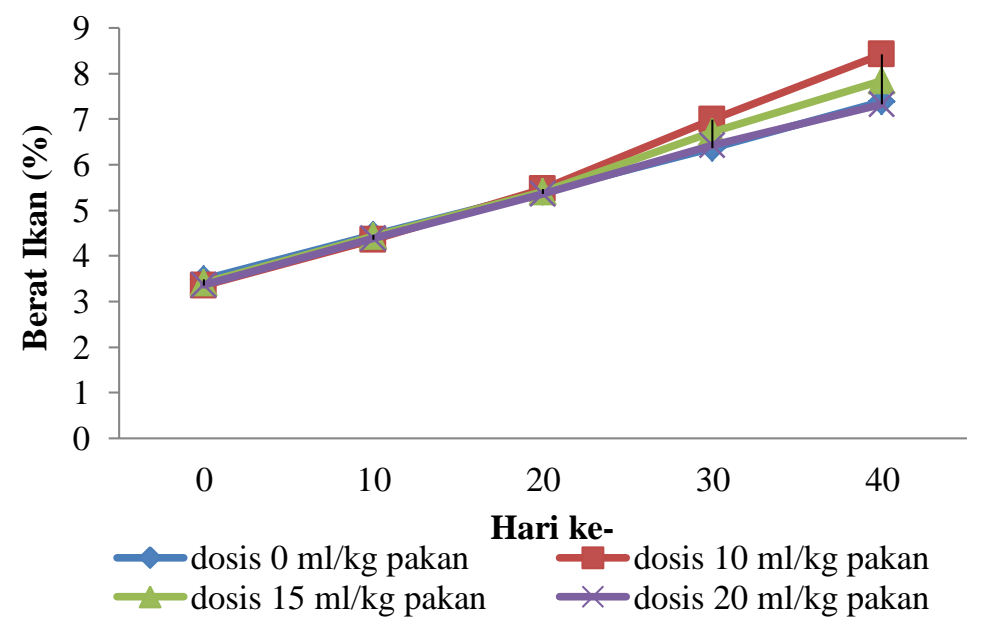

Gambar 4. Rata-rata laju pertumbuhan spesifik benih ikan kerapu bebek

Pertumbuhan harian berfungsi untuk menghitung persentase pertumbuhan berat atau panjang ikan per hari. Berdasarkan hasil pengamatan pertumbuhan berat harian ikan kerapu bebek ( $C$. altivelis) sesuai dengan pemberian viterna dengan dosis yang berbeda pada pakan menunjukkan pertumbuhan berat rata-rata harian yang berbeda pula. Pertumbuhan berat harian tertinggi terdapat pada perlakuan B $(12,68 \%)$ kemudian diikuti C $(11,10 \%)$, D $(9,92 \%)$ dan A $(9,77 \%)$. Kenaikan bobot harian ikan pada setiap perlakuan selama penelitian menunjukkan bahwa seluruh hewan uji mengalami pertumbuhan.

Hal ini erat kaitannya dengan kecepatan pencernaan dan pemakaian energi dengan kata lain ikan yang memperoleh pakan untuk proses metabolisme akan lebih meningkat pertumbuhannya karena memperoleh nutrisi yang cukup untuk diserap dari pakan yang dikonsumsinya sehingga perlakuan dengan dosis viterna $10 \mathrm{ml} / \mathrm{kg}$ lebih tinggi 
pertumbuhan berat hariannya.Permasalahan ini diduga ikan yang diberikan dosis viterna $15 \mathrm{ml} / \mathrm{kg}$ dan $20 \mathrm{ml} / \mathrm{kg}$ tidak mampu menyerap pakan yang diberikan dengan optimal.

Data bobot ikan menunjukkan adanya penambahan berat ikan kerapu bebek. Hal ini sesuai menurut Asma et al. (2016), jumlah pemberian pakan yang sudah sesuai dengan kapasitas lambung dan kemampuan cerna untuk menghasilkan pertumbuhan benih ikan yang optimal. Selanjutnya menurut Hardianti et al. (2016), menyatakan bahwa pertumbuhan ikan dapat terganggu apabila kelebihan energi untuk gerak dan protein yang berasal dari makanan yang telah digunakan oleh tubuh untuk mengganti sel-sel yang rusak.

Sedangkan hasil pengamatan pertumbuhan panjang harian ikan kerapu bebek ( $C$. altivelis), sesuai dengan pemberian viterna dengan dosis yang berbeda pada pakan menunjukkan pertumbuhan panjang rata-rata harian yang berbeda pula. Pertumbuhan panjang harian ikan kerapu bebek yang tertinggi terdapat pada perlakuan B sebesar 20,18 \%, dilanjutkan dengan perlakuan $\mathrm{C}$ sebesar $18,35 \%$, pertumbuhan $16,30 \%$ per hari terjadi pada perlakuan $\mathrm{D}$ dan selanjutya yang terendah pada perlakuan A yakni $14,00 \%$. Kenaikan bobot harian ikan pada setiap perlakuan selama penelitian menunjukan bahwa seluruh ikan uji mengalami pertumbuhan.

Pertumbuhan ikan kerapu bebek terjadi karena adanya pasokan energi yang terkandung dalam pakan. Energi dalam pakan yang dikonsumsi melebihi kebutuhan energi yang dibutuhkan untuk pemeliharaan tubuh dan aktifitas tubuh lainya. Sehingga kelebihan energi tersebut dimanfaatkan untuk pertumbuhan. Mulyadi (2011), menyatakan bahwa pertumbuhan terjadi karena adanya kelebihan energi yang berasal dari pakan setelah dikurangi oleh energi hasil metabolisme dan energi yang terkandung dalam feses. Pariyanti (2007), menyatakan bahwa faktor yang mempengaruhi pertumbuhan ikan dapat digolongkan menjadi dua yaitu faktor internal dan eksternal. Faktor internal merupakan faktor yang berhubungan dengan ikan itu sendiri seperti umur, dan sifat genetik ikan yang meliputi keturunan, kemampuan untuk memanfaatkan makanan dan ketahanan terhadap penyakit. Faktor eksternal merupakan faktor yang berkaitan dengan lingkungan tempat hidup ikan yang meliputi sifat fisika dan kimia air, ruang gerak dan ketersediaan makanan.

Berdasarkan hasil analisis variansi (ANOVA), perlakuan dengan dosis vitamin viterna yang berbeda berpengaruh nyata terhadap pertumbuhan bobot mutlak benih ikan kerapu bebek dengan nilai probabilitas $0,00<0,05$. Kemudian dilakukan uji lanjut Least Significant Difference. Hasilnya perlakuan A berbeda nyata dengan perlakuan $\mathrm{B}$, dan $\mathrm{C}$, namun tidak berbeda nyata perlakuan $\mathrm{D}$.

\section{Kelulushidupan (Survival Rate)}

Nilai tingkat kelulushidupan benih ikan kerapu bebek selama masa pemeliharaan adalah $100 \%$ untuk seluruh perlakuan disajikan pada Tabel 1.

Tabel 1. Kelulushidupan (\%) benih ikan kerapu bebek selama 40 hari

\begin{tabular}{ccccccc}
\hline \multirow{2}{*}{ Perlakuan } & $\begin{array}{c}\text { Viterna } \\
\text { (ml/kg pakan })\end{array}$ & \multicolumn{3}{c}{ Ulangan } & \multirow{2}{\text{Total}}{} & $\begin{array}{c}\text { Rata-rata } \\
\text { Ulangan }\end{array}$ \\
\cline { 3 - 5 } & Std. Deviasi \\
\hline A & $(0)$ & 100 & 100 & 100 & 300 & $100 \pm 0$ \\
B & $(10)$ & 100 & 100 & 100 & 300 & $100 \pm 0$ \\
C & $(15)$ & 100 & 100 & 100 & 300 & $100 \pm 0$ \\
D & $(20)$ & 100 & 100 & 100 & 300 & $100 \pm 0$ \\
\hline
\end{tabular}


Hasil pengamatan ikan kerapu bebek terhadap kelangsungan hidup memperoleh hasil yang sama antar perlakuan yaitu 100\%. Hal ini membuktikan bahwa kualitas air pada penelitian ini terkontrol dengan baik dan masih dalam kondisi ideal untuk kehidupan ikan kerapu bebek sehingga tidak mempengaruhi nilai kelangsungan hidupnya. Selain itu penggunaan dosis viterna yang tepat dan cocok untuk ikan kerapu bebek diduga dapat menentukan tingkat kelulushidupan ikan.

Hal ini sesuai dengan pernyataan Handayani et al. (2014); Raudah et al. (2018), dimana tingginya presentase kelangsungan hidup ikan disebabkan kualitas air yang digunakan masih dalam kondisi ideal untuk pemeliharaan ikan. Dimana kelangsungan hidup dipengaruhi oleh kualitas air, kebutuhan pakan, umur ikan dan lingkungan. Umur ikan berhubungan dengan pakan, sehingga pakan harus tersedia secara terus menerus dan sesuai dengan kebutuhannya.

\section{KESIMPULAN DAN SARAN Kesimpulan}

Berdasarkan hasil penelitian yang diperoleh, dapat disimpulkan bahwa laju pertumbuhan benih ikan kerapu bebek pada perlakuan terbaik adalah perlakuan viterna dengan dosis $10 \mathrm{ml} / \mathrm{kg}$ pakan, dimana teradapat perbedaan pertumbuhan dan kelulushidupan benih ikan kerapu bebek pada pakan yang ditambahkan dosis viterna berbeda.

\section{Saran}

Disarankan untuk penelitian selanjutnya menggunakan multivitamin viterna yang dicampurkan pada pakan pelet dengan dosis $10 \mathrm{ml} / \mathrm{kg}$. Namun perlu dilakukan uji lanjut menggunakan dosis viterna yang berbeda terhadap jenis ikan kerapu lainya, sehingga dapat bermanfaat bagi pembudidaya atau masyarakat pada umumnya.

\section{DAFTAR PUSTAKA}

1. Asma, N., ZA. Muchlisin, I. Hasri. (2016). Pertumbuhan dan Kelangsungan Hidup Benih Ikan Peres (Osteochillus vittatus) pada Ransum Harian yang Berbeda. Jurnal Ilmiah Mahasiswa Kelautan dan Perikanan Unsyiah, volume 1(1), pages 1-11.

2. Effendi. (1979). Metode Biologi Perikanan. Dwi Sri, Bogor. 112 P

3. Hadadi, A., Herry, KT. Wibowo, E. Pramono, A. Surahman, dan E. Ridwan. (2009). Aplikasi Pemberian Maggot sebagai Sumber Protein dalam Pakan Ikan Lele Sangkuriang (Clarias sp.) dan Gurame (Osphronemus gouramy Lac.). Laporan Tinjauan Hasil Tahun 2008. Balai Pusat Budidaya Air Tawar Sukabumi. hal. 175 - 181.

4. Handayani, I., E. Nofyan, M. Wijayanti. (2014). Optimasi Tingkat Pemberian Pakan Buatan terhadap Pertumbuhan dan Kelangsungan Hidup Ikan Patin Jambal (Pangasius djambal). Jurnal Akuakultur Rawa Indonesia, volume 2(2), pages 175-187.

5. Hardianti, Q., Rusliadi, Mulyadi. (2016). Effect of Feeding Made with Different Composition on Growth and Survival Seeds of Barramundi (Lates calcarifer, Bloch). Jurnal Penelitian Perikanan Indonesia, volume 9(1), pages 1-10.

6. Hendrosaputro, R., Rully, Mulis. (2015). Pengaruh Pemberian Viterna Pplus dengan Dosis Berbeda pada Pakan terhadap Pertumbuhan Benih Ikan Lele Sangkuriang di Balai Benih Ikan Kota Gorontalo. Jurnal Ilmiah Perikanan dan Kelautan. Volume 3(2).

7. Kordi, MG. (2009). Budidaya Perairan. Citra Ditya Bakti. Bandung.

8. Kurnia, A. (2008). Dicari Pakan Ikan Berkualitas, Murah dan Ramah Lingkungan. Artikel Iptek. http://www.beritaiptek.com. 3 hlm 
9. Muchlisin, ZA., F. Afrido, T. Murda, N. Fadli, AA. Muhammadar, Z. Jalil, C. Yulvizar. (2016). The Effectiveness of Experimental Diet with Varying Levels of Papain on The Growth Performance, Survival Rate and Feed Utilization of Keureling Fish (Tor tambra). Biosaintifika, volume 8(2), pages 172-177.

10. Mufidah, WB., BS. Rahardja, WH. Satyantini, W. H. (2009). Pengkayaan Daphnia sp. dengan Viterna terhadap Kelangsungan Hidup dan Pertumbuhan Larva Ikan Lele Dumbo (Clarias gariepnus). Jurnal Ilmiah Perikanan dan Kelautan volume 1(1).

11. Mulyadi, AE. (2011). Pengaruh Pemberian Probiotik pada Pakan Komersil terhadap Laju Pertumbuhan Benih Ikan Patin Siam (Pangasius hypophthalmus). Skripsi. Fakultas Perikanan dan Ilmu Kelautan. Unpad. Jatinangor

12. Pariyanti, F. (2007). Pengaruh Penambahan Suplemen Viterna dalam Pakan terhadap Laju Pertumbuhan dan Rasio Konversi Pakan Lobster Air Tawar (Cherax quadricarinatus). Skripsi. Jurusan Perikanan. Fakultas Peternakan - Perikanan. Universitas Muhammadiyah Malang.

13. Rayes, RD., IW. Sutresna, N. Diniarti, AI. Supii. (2013). Pengaruh Perubahan Salinitas terhadap Pertumbuhan dan Sintasan Ikan Kakap Putih (Lates calcarifer Bloch). Jurnal Kelautan, volume 6(1), pages 47-56.

14. Raudah, P., I. Suharman, H. Alawi. 2018. Utilization of Leucaena Leaves Meal Gung (Leucaena leucocephala) Fermented by Aspergillus niger as Subtitution of Soybean Meal in the Diets on the Growth of Thai Cat Fish (Pangasius hypophthalmus). Jurnal Perikanan dan Kelautan, volume 23(2), pages 1-8 